\title{
E-BUSINESS DEVELOPMENT: THE COMPARATIVE STUDY OF THE CZECH REPUBLIC AND THE UKRAINE Victoriya KULYK ${ }^{\mathrm{a}}$, Dagmar ŠKODOVÁ PARMOVÁ ${ }^{\mathrm{b}}$
}

\footnotetext{
a Poltava University of Economics and Trade, Koval St., 3, Poltava, 36014 e-mail: kutsenko_va@mail.ru

${ }^{\mathrm{b}}$ University of South Bohemia, Faculty of Economics, Studentská 13, České Budějovice CZ-37004 email: parmova@jcu.cz
}

Cite this article: Kulyk, V., Škodová Parmová, D. (2017). E-business Development: The Comparative Study of the Czech Republic and the Ukraine. Deturope, 9, 1: 80-110

\begin{abstract}
This paper summarizes the current basis for e-business development in the EU with the focus on the Czech Republic with comparison with the associated Ukraine. After description of managerial and accountancy aspects for the e-commerce way of selling goods and services and after summarizing the legislative framework there is an analyses for future Human Resources Management according to the needs of Industry 4.0 introduced. After this theoretical part there you can find the comparison of the particular tools for e-business support and training of employees in related services between the Czech Republic and the Ukraine. As conclusion there is a list of recommendation summarized with the focus on how to improve the situation of e-business in nowadays Ukraine.
\end{abstract}

Keywords: e-commerce, accounting in e-business, HRM for e-commerce.

\section{INTRODUCTION}

Transformation of a significant number of business processes in the on-line sphere led to the emergence and further improvement of a new sector of the economy - e-business. E-business is a business activity that relies on the use of the Internet for modification of internal and external relations at an enterprise in order to gain revenue.

E-business is increasing continuously in various sectors of economy in many countries. According to the data of Global B2C Report 2016 (ECOMMERCEWIKI, 2016) the number of customers who shopped online accounted for 1,436 million people in 2015. Total online sales of goods and services obtained by e-business enterprises equalled $\$ 2,273$ billion in 2015 (estimated for 2016 was $\$ 2,671$ billion) that was significantly higher than in the preceding year, the growth was $19.9 \%$. The share of goods and services sold online in the total amount of goods and services sold worldwide made up 5.6\% in 2014. Global B2C e-commerce sales of products and services continued to grow significantly in 2015 (ECOMMERCE EUROPE, 2015). In 2016, total retail sales across the globe were about to reach $\$ 22,049$ trillion, $6.0 \%$ more than previous year. eMarketer estimates sales will top \$27 trillion in 2020, even as annual growth rates slow over the next few years, as explored in a new eMarketer report (2016). 
Europe is the most mature market of e-commerce, 274 million people from this region shopped online in 2015 (ECOMMERCE EUROPE, 2015). According to UNCTAD B2C Index 2016 (UNCTAD, 2016), six European countries were in the list of top-10 leaders in ebusiness, such as Luxemburg (ranked $1^{\text {st }}$ ); Iceland (ranked $2^{\text {nd }}$ ); Norway (ranked $3^{\text {rd }}$ ); Finland (ranked $6^{\text {th }}$ ); UK (ranked $8^{\text {th }}$ ); Switzerland (ranked $9^{\text {th }}$ ). Besides that, three countries from the Asia-Pacific region and one from North America were also listed among top-10 countries. Four following indicators were used to calculate UNCTAD B2C Index 2016: 1) Internet users; 2) secure servers; 3 ) credit card penetration; 4) postal reliability score.

The European countries mentioned above are very efficient in e-business, because they are creating and using some competitive advantages. For example, Luxembourg can offer welldeveloped financial sector to e-business players. This sector attracts international corporations, the head-offices of Amazon, PayPal, Apple, etc. are situated there. The low rate of VAT concerning e-books encourages some spheres of e-business in this country. Despite being landlocked, Luxembourg has a developed logistics network and it is the second largest European country, which has the highest postal rate of reliability.

In the second place is Iceland. Internet penetration rate is very high in this country; people can use different types of credit cards, which facilitate international online purchases; the network of post offices is large and reliable in this country.

Ukraine was ranked $54^{\text {th }}$ in 2016 (58 $8^{\text {th }}$ in 2014$)$, between Romania $\left(46^{\text {th }}\right.$ in 2014$)$ and Costa Rica $\left(49^{\text {th }}\right.$ in 2014). According to this information, Ukraine improved its position in comparison with 2014. At the same time, it can be seen that $54^{\text {th }}$ place among 137 countries is not good enough for Ukraine.

If we look at the Czech Republic ranks, it was $29^{\text {th }}$ in 2016 (28 $8^{\text {th }}$ in 2014). Subsequently, it can be noted that the Czech Republic overcame a half of way between Ukraine and the leading countries at e-business.

In 2015, the Czechs spent 3 billion euros in domestic online stores. Compared to the previous year, the Czech e-commerce industry achieved growth of over 20 percent. According to the data of the Czech association for electronic commerce, the local e-commerce grew by at least 15 percent in 2016. During 2015, e-commerce in the Czech Republic accounted for 8.1 percent of total retail turnover (APEK, 2016). According to preliminary estimates (Statista, 2016), the revenue in the e-market is set to reach $\$ 2,610$ million in 2017. Revenue is expected to show an annual growth rate (CAGR 2017-2021) of 6.7\% resulting in a market volume of $\$ 3,384$ million in 2021 . User penetration will be at $55.9 \%$ in 2017 and is expected to hit $59.2 \%$ in 2021 . The average revenue per user (ARPU) currently amounts to $\$ 524.30$. This suggests that the Czech Republic experience in running e-business can be very useful for Ukraine. 
Therefore, it can be noted, that e-business is a popular economic activity, which is developing at a high speed worldwide. E-business is one of the most perspective directions of business development as it has considerable advantages in selling goods and services to potential consumers in comparison with other kinds of trading activity.

The main advantages of e-business activity are the following: 1) e-business allows potential consumers to choose and compare goods and services independently, by the most comfortable method and in proper time for them; 2) possibilities of e-business allow to offer customers the widest list of goods and services possible; 3) organizational features of functioning of e-business enterprises allow to offer the most affordable prices to potential customers.

E-business plays an important role and makes a large-scale influence in the world markets. It is held that, under the influence of e-business, the quality of life in the first decade of the $21^{\text {st }}$ century will change more than in the hundred years of the $20^{\text {th }}$ century. Based on the first experiences in the development of e-commerce, e-governance and e-banking, it may be concluded that they open up for major opportunities, and start bringing in quality changes in the business activities as well as in the life of citizens (Kneżević, 2015).

\section{OBJECTIVES AND METHODOLOGY}

In this study, we will research e-business in three aspects, such as: 1) the main directions of ebusiness development and its obstacles; 2) the features of management in e-business and the components of e-business information system, which include accounting; 3) professional requirements needed for people who will work in the virtual economy in the near future. Using the experience of EU-member states and the Czech Republic in particular, we will offer some recommendations for e-business development in Ukraine.

In terms of literature review, two research gaps concerning the running of e-business in developing countries (e.g. Ukraine) were noted:

1. Theoretical - no in-depth analysis of the improvement in e-legislation to shape virtual environment.

2. Empirical - an incomplete description of new accounting advantages, experience and its implementation in business under the use of information and communication technologies in virtual companies. The description of the research can be acquired and the generalization of empirical knowledge fills this gap in partially.

The above-described problem definitely leads to a considerable need to conduct research in this area. This study is undertaken with the following objectives:

1. To evaluate the influence of globalization on doing and development of e-business; 
2. To determine the influence of e-management on accounting system;

3. To identify professional skills needed in virtual economy and features of education system, which may help students to acquire these skills.

Considering the defined aims of the paper, there is a need to provide a review of the literature on the understanding of e-business models and trends, its obstacles considering elegislation, e-management and accounting system in e-business as well as e-learning features.

The rest of the paper is organized as follows. The next section presents literature review on e-business aspects, which will be considered in the research (e-business evolution and directions of development; e-legislation framework as advantages and disadvantages of ebusiness; accounting as an information system to manage e-business; professional requirements and e-education). Next section proposes a review of e-business development and its trends, which affect the management of e-business. Then, we define how accounting system should be changed under the influence of information economy. Following this, we formulate suggestions, which are based on conclusions from the previous parts of the research and which can be used in education system to improve its quality in accordance with ebusiness requirements. Finally, we conclude the study with a list of suggestions, which can improve e-business in Ukraine.

We will use the content analyses to research the documents and the current studies according to e-business and to the future needs in the labour market as well. The syntheses will be based on the recommendations from the developed markets in e-business to improve the knowledge and the education of experts in higher education institutions in the Ukraine to raise the quality of this kind of business in this country.

\section{LITERATURE REVIEW}

Technological development is changing the way companies do business. One of the main sources of these transformations is the Internet, which became of great importance for doing e-business and to improve the productivity of economic activities in general. In this study we use the concept "e-business" in accordance with Beynon-Davies' definition, such as "electronic business or e-business might be defined as the utilization of information and communication technologies to support all the activities of business" (Beynon-Davies, 2007).

The studies of different scientists were used to examine the main stages of e-business evolution and the components of e-business, such as internal models of e-business which were proposed by Osterwalder, Pigneur, and Tucci (2005); Markides and Sosa (2013); and Dasilva and Trkman (2014). E-business is recognized as a strategy that coordinates business processes 
across organizational boundaries effectively. Information and communication technologies (ICT) and e-business are affecting our economic progress, social development, and the environment profoundly and in a complex manner. In order to further explore the relationship between e-business and the environment Yi and Thomas (2009) investigated its components. Aspects of e-business evaluation were investigated by Amit and Zott (2001); Chaston and Mangles (2002). The impact of external factors on e-business has been explored by Moreira de Souza and César de Sousa Batista (2017).

The issues concerning accounting in e-business have been considered in the articles of many scientists, following this, the aspects of using information and communication technologies in accounting have been explored. In terms of ICT-use, the problems involved in accounting improvement were investigated in the articles of the following European scientists: Gonzálbez and Rodríguez (2012); Grande, Estébanez and Colomina (2011); Poel, Marneffe and Vanlaer (2016). Taking into account significant contribution of the scientists into the development of accounting aspects mentioned above, it should be noted that distinguishing accounting features at e-business companies should be more thorough and requires further investigation.

The connection between management effectiveness organizational learning and knowledge management capabilities towards e-business implementation success was investigated by Khamis, Sulaiman and Mohezar (2014). These days, the problems of the future of education system are becoming more and more relevant; they were highlighted in numerous researches, such as Kotb and Roberts (2011); Tanaka and Sithole (2015); Pan and Seow (2016).

\section{RESULTS}

\section{E-business evolution and current challenges}

In the future, business will be conducted through flexible networks of interdependent organizations all over world. It will be global, open and collaborative, dynamic and adoptive, frictionless and consistent. Information and communication technologies will be one of the most essential presuppositions for successful business development. All industries will be affected by such kind of transformations.

Electronic communications started in US in 1958. It was the research on the US ARPA project, which increased technological progress on networks, protocols and software and led to the ARPAnet (1969). More inventions followed such as the EDI (1972) and the WWW (1992, CERN) which was created as a management system of multimedia resources that 
permits data exchange between computers. The development of e-commerce was fast: in the period of 1994-1997 many business firms created a web page on the Internet without electronic transactions (e.g. amazon.com, e-bay). In the period of 1997-2000 the first electronic transactions were made possible, and since 2000 e-commerce is widely considered as a way of increasing profit (Col., 2013).

At the beginning, in the mid-90s, ICT were used in business for selling and paying for goods and services, which was well-known as e-commerce. Then, when ICT were implemented in all chains of business processes, such as ERP, CRM, EAM, and HRmanagement, researchers prefer to call this kind of business activity e-business. Nowadays, ebusiness includes not only e-commerce, but also m-commerce (mobile commerce) as a new kind of business with ICT use.

Nowadays, enterprises, which belong to e-business, can be conventionally divided into four layers (table 1).

Table 1 The Layers of Companies Related to E-business

\begin{tabular}{|l|l|c|}
\hline \multicolumn{1}{|c|}{ Layer } & \multicolumn{1}{|c|}{ Types of companies } & Examples \\
\hline $\begin{array}{l}\text { Layer 1 Ine Internet } \\
\text { Therastructure layer }\end{array}$ & $\begin{array}{l}\text { Companies that provide the infrastructure for network } \\
\text { and its services (Network hardware provider, ISP, } \\
\text { Software companies, Server manufacturers) }\end{array}$ & $\begin{array}{c}\text { MCI, TCS, Cisco, } \\
\text { AOL, AT\&T, } \\
\text { Qwest }\end{array}$ \\
\hline $\begin{array}{l}\text { Layer 2 Internet } \\
\text { The } \\
\text { applications layer }\end{array}$ & $\begin{array}{l}\text { Companies that provide software for enabling } \\
\text { transactions and services (Consultancy software } \\
\text { developers, Multimedia development providers) }\end{array}$ & $\begin{array}{c}\text { Netskape, Adobe, } \\
\text { Microsoft, IBM, } \\
\text { Oracle }\end{array}$ \\
\hline $\begin{array}{l}\text { Layer 3 Internet } \\
\begin{array}{l}\text { The } \\
\text { intermediary layer }\end{array}\end{array}$ & $\begin{array}{l}\text { Companies that act like the platform for transactions } \\
\text { (Online portals, Content providers, Internet brokers) }\end{array}$ & Yahoo, eBay \\
\hline $\begin{array}{l}\text { Layer 4 Internet } \\
\text { The } \\
\text { commerce layer }\end{array}$ & $\begin{array}{l}\text { Companies that directly interact with the customers to } \\
\text { sell their products (Subscription based companies, T- } \\
\text { tailors, Online ticket sellers) }\end{array}$ & $\begin{array}{c}\text { Flipkart, Amazon, } \\
\text { Dell }\end{array}$ \\
\hline
\end{tabular}

Source: E-commerce essentials (2016)

Thus, e-Commerce Directive 2000/31/EC (ECD) highlights other classification for groups of ecompanies within the Internet intermediary layers (European Commission, 2000):

1) web hosting providers (including domain name registrars) and data processing, transforming data, which prepare data for dissemination or store data or content on the internet for others (Navisite, Akamai, OVH, Easyspace, Rackspace, Regsiter.com, Leaseweb, Go daddy, GMO Internet INC.);

2) Internet search engines and portals, which provide help navigating on the Internet (Google, Yahoo!, Baidu, Never, MSN, Bing);

3) e-commerce intermediaries, enabling online buying or selling, but don't owe the goods sold (Amazon, eBay, Allegro, Ali Baba, Priceline.com); 
4) participative networking platforms, which do not create or own the content being published. They provide help in creating content and social networking (Facebook, LinkedIn; Youtube, Ohmynews);

5) Internet access and service providers (ISPs). They prove access to the Internet to households, business and government (Verizon, Comcast, NTT, Internet Initiative Japan, BT, Free fr, Vodafone, Orange, Tmobile, MTN);

6) Internet payment systems, which process Internet payments (Visa, Paypal, Mastercard).

E-business companies belonging to every layer, have internal and external environment. The evolution of e-business enterprises depends on the components of internal and external environment. Previous studies in e-business were used to construct the model of internal and external environment of e-business enterprises (Osterwalder, 2004, Osterwalder et all. 2005, Durbhakual, Kim 2011).

The external environment consists of four aspects including the following: 1) country characteristics (corruption, human capital); 2) government dimension (e-government development, e-participation, government policy and vision); 3) business dimension (business competitiveness, business environment); 4) technology dimension (ICT infrastructure, technology innovation, technology readiness).

This model illustrates what aspects of the internal environment have to consider and what dimensions of external environment should be taken into account by managers. The pillars of internal aspect of e-business include nine building blocks of business model. Product pillar consists of Value Proposition building block. A Value Proposition is an overall view of a company's bundle of products and services that are of value to the customer. There are three building blocks of business model in Customer Interface Pillar, such as: Target Customer, Distribution Channel and Relationship. The Target Customer is a segment of customers a company wants to offer value to. A Distribution Channel is a means of getting in touch with the customer. The Relationship describes the kind of link a company establishes between itself and the customer. Infrastructure Management Pillar includes next blocks: Value Configuration, Capability and Partnership. The Cost Structure is the representation in money of all the means employed in the business model. The Revenue Model describes the way a company makes money through a variety of revenue flows (Osterwalder, 2004).

To sum up, the components of internal and external environment of e-business enterprises influence decision-making process. In terms of every component of e-business environment, the managers of virtual enterprises in developing countries face numerous challenges (table 2). 
Table 2 Challenges Facing E-managers in Developing Countries

\begin{tabular}{|c|c|c|}
\hline $\begin{array}{l}\text { Components of e- } \\
\text { business } \\
\text { environment }\end{array}$ & $\begin{array}{l}\text { Challenges facing e- } \\
\text { managers in developing } \\
\text { countries }\end{array}$ & International experience in solving these problems \\
\hline \multicolumn{3}{|c|}{ Components of external environment } \\
\hline $\begin{array}{l}\text { Country } \\
\text { Characteristics }\end{array}$ & $\begin{array}{l}\text { Political instability } \\
\text { High level of corruption } \\
\text { in country }\end{array}$ & Politic and economic reforms \\
\hline $\begin{array}{l}\text { Government } \\
\text { Dimension }\end{array}$ & $\begin{array}{l}\text { Trade barriers } \\
\text { Differences in legal } \\
\text { regulation of trade } \\
\text { activity }\end{array}$ & $\begin{array}{l}\text { Simplification of VAT taxation for different kinds of } \\
\text { e-business enterprises among the European Union } \\
\text { member-states }\end{array}$ \\
\hline $\begin{array}{l}\text { Business } \\
\text { Dimension }\end{array}$ & $\begin{array}{l}\text { High level of } \\
\text { competition at the } \\
\text { international market }\end{array}$ & $\begin{array}{l}\text { Governments may provide an access for various } \\
\text { versions of web-sites (where different prices are } \\
\text { established) for customers from different countries }\end{array}$ \\
\hline $\begin{array}{l}\text { Technology } \\
\text { Dimension }\end{array}$ & $\begin{array}{l}\text { Insufficient level of } \\
\text { infrastructure } \\
\text { development }\end{array}$ & $\begin{array}{l}\text { Creation of a new legislative base that involves } \\
\text { regulation of trade activity through mobile phones } \\
\text { and other gadgets that will be used at e-business } \\
\text { sphere in the near future }\end{array}$ \\
\hline \multicolumn{3}{|c|}{ Components of internal environment } \\
\hline Product & $\begin{array}{l}\text { High prices and } \\
\text { limitations in selling and } \\
\text { usage of separate types } \\
\text { of commodities }\end{array}$ & $\begin{array}{l}\text { Unification of legislation among the European Union } \\
\text { member-states }\end{array}$ \\
\hline $\begin{array}{l}\text { Customer } \\
\text { Interface }\end{array}$ & $\begin{array}{l}\text { Insufficient level of } \\
\text { customers' trust to } \\
\text { Internet-shops } \\
\text { Language barrier }\end{array}$ & $\begin{array}{l}\text { Customer personal data protection } \\
\text { Prevention and fighting e-crimes }\end{array}$ \\
\hline $\begin{array}{l}\text { Infrastructure } \\
\text { Management }\end{array}$ & $\begin{array}{l}\text { Lack of legislation } \\
\text { regulating cooperation } \\
\text { in e-business }\end{array}$ & $\begin{array}{l}\text { Creation of identical requirements for e-business } \\
\text { activity considering regional aspect. In this case, it is } \\
\text { important to create equal conditions for all enterprises } \\
\text { that perform in e-business sphere and implement } \\
\text { these requirements at legislative level }\end{array}$ \\
\hline Financial Aspects & $\begin{array}{lr}\text { Differences } & \text { in } \\
\text { accounting } & \text { and } \\
\text { Financial Statement }\end{array}$ & Implementation of IRFS \\
\hline
\end{tabular}

Source: Own compilation.

One of the ways to solve these problems is the creation of e-legislation connected with ebusiness demands. In our opinion, EU member-states and other developed countries have a huge experience in tackling these challenges; some aspects can be used in Ukraine.

\section{E-legislation}

The problems highlighted above arise during performing economic activity by e-business enterprises and are more or less common in developing countries. However, attempts to solve these issues, in terms of legislative regulation of e-business, have been initially made in EUcountries.

E-business takes a significant place in international trade, as evidenced by numerous attempts on behalf of NGOs and state bodies to harmonize e-commerce regulations. E-commerce transactions should be legally straightforward. E-entrepreneurs get money up front for the sale, in return for 
delivery of a product as described within the timeframe specified. A standard set of terms and conditions should cover the vast majority of transactions (ECOMMERCE GUIDES, 2016).

The Internet is one of the most regulated areas of society. In the EU, there are at least fifteen Directives, proposals and recommendations to try to regulate e-commerce. The EU has attempted to assert regulatory control of online issues and it is hoped that as each country incorporates various EU legislative packages into local law, the opportunity will be taken to abolish outdated provisions and set forth an e-commerce-friendly approach throughout Europe (Jahankhani, 2002).

The first of them is e-Commerce Directive 2000/31/EC (ECD), which has created the basic legal framework for online services, including electronic commerce in the Internal Market. The purpose of the Directive is to remove obstacles to cross-border online services in the European Union and provide legal certainty to business and citizens in cross-border online transactions.

The main feature of the ECD is its horizontal application such as provision of "information society services" (ISS) (e.g. online sellers of goods and services, ISPs, search engines, etc.). ECD complements other EU legislation, for example, identifies procedural rules and substantive rules. At the same time, ECD does not apply to taxation, data protection and gambling activities.

In 2010, the European Commission developed its EU 2020 Strategy by establishing three development priorities on smart, sustainable and inclusive growth. In addition, the EU 2020 strategy proposed seven flagship initiatives: 1) an innovation Union; 2) youth on the move; 3) a digital agenda for Europe; 4) a resource-efficient Europe; 5) an industrial policy for the globalisation era; 6) an agenda for new skills and jobs; 7) a European platform to tackle poverty (European Commission, 2010 and 2012).

In terms of EU 2020 Strategy, the Directive 2011/83/EU89 on consumer rights will change the requirements for pre-contractual information was adopted. It repeals previous directives on distance and off premises contracts (85/577/EEC and 97/7/EC) and (re)establishes consumer rights on the basis of full harmonization. New harmonised rules on the passing of risk in sales contracts and the default time limit for the delivery of goods as well as a ban on hidden charges, on pre-ticked boxes which impose surcharges higher than the trader's actual costs for the use of a certain payment means (e.g. credit cards) and on charges for telephone hotlines higher than the standard telephone rate for calls. However the Directive 2011/83/EC still presents certain disadvantages: There is still fragmentation of national laws on remedies (guarantees) and unfair contract terms since national laws still apply on the validity, termination or enforceability of a contract; transfer of ownership of goods; gambling and healthcare services. In addition, member States may impose linguistic requirements on consumer contracts (Col., 2013). 
The Digital Single Market is the first pillar of the Digital Agenda. Therefore, nowadays, the European Commission is working on the improvement of European legislation, aiming to remove barriers between e-business legislation in different countries and create a common digital market in Europe. The main activities of the European Commission for the improvement of e-business legislation are the following:

- stimulation of e-business enterprises involved in cross-border trade, particularly small and medium e-business enterprises; this improvement relates to the harmonization of contract law, consumer rights protection, and more structured of parcels delivery;

- simplification of VAT taxation as it is an important problem for small and medium enterprises that needs to be solved urgently (Ecommerce Europe, 2016).

The major part of the problems e-business European enterprises face has been resolved in the political sphere. It especially concerns the following: 1) problems concerning online safety and data protection can be solved by stimulating investments in innovative products in e-industry; 2) consumer rights protection can be enhanced through self-regulation of the market and a high rate of competition; 3) legislative regulation of payments made with mobile gadgets should be improved considerably; 4) implementation legislation that would harmonize VAT within EU member-states and introduction of the Mini One-Stop Shop Scheme (MOSS); 5) improvement of e-logistics by providing more efficient parcels delivery from the country where the company performs its activity.

To sum up, many aspects of e-business are regulated by current legislation in the EU, such as: shipping and delivery policy; refund policy; protecting e-entrepreneurs interests; standard ecommerce terms and conditions; data protection; protecting customer's privacy online; online advertising compliance; taxes in e-business; customer financial data security. At the same time, there are some obstacles, which discourage e-business development in the EU. Overcoming these obstacles involves the following:

- harmonization and synthesis of the different legal systems, regulations, and laws in different member countries for e-business complete solutions across the EU;

- development of the contractual framework, related meta methodology, and associated legal information systems;

- development of contractual templates and related guidelines for online contracting;

- acceleration of regulatory studies on online security, DRM, and IPR;

- proposal of tentative mechanisms for cross border compensation and dispute resolution, selfregulation, and relevant codes of conduct;

- initiation of holistic approaches regarding applied ontologies and artificial intelligence for several key areas which hinder SEEM deployment such as natural language processing and creating 
a legal/regulatory framework for European laws and regulations;

- development of regulations relevant to e-business registries, in particular user registry information validation and confirmation, and defining the roles and legal responsibilities of certification authorities;

- development of specific regulations tailored for SMEs to facilitate their trusted participation in the SEEM and prevent them from facing alone unaffordable disputes in other countries and under unfamiliar laws;

- development of ICT services for online dispute resolution as a key element for trust building in e-business across Europe. Although much depends on the general social infrastructure, the SEEM developers and general interest groups should work out effective online/offline dispute resolution services to solve

- any potential conflicts generated in the SEEM;

- inclusion of the ethical side in all the studies of regulations about intercompany and even interpersonal e-business relations across Europe (Renl et al., 2007).

Barriers for increased uptake of ICT are very much related to the lack of resources, insufficient knowledge about ICT costs and benefits, absence of skills, as well as the prevailing traditions and culture in this sector. Therefore, there is still great potential for further ICT uptake, for example: production planning systems, ERP systems with financial components, inventory management systems, supply chain management (SCM) and mobile solutions. Another conclusion is that business process integration may be a key driver for ICT adoption in the future.

This indicates that it could be cost-effective to launch policy initiatives in order to increase the level of awareness of e-business applications. In this context, the following three areas of policy actions have been identified as appropriate: 1) improving ICT skills; 2) increasing the awareness of ICT benefits and potentials; 3) facilitating the process of interoperability (Gatautis, 2007).

\section{Accounting as a part of e-business management system}

According to the Standish Group Report (2013), the most important reasons for e-business failure are the following: a) inappropriate project scope definition; b) inappropriate project communication; c) lack of appropriate project management competencies. So, well-prepared business strategy and good management communication are extremely important for effective running of e-business. Firstly, before researching the main features of e-management, we should study the impact of ITC-technology on different components of e-business (table 3). 
Table 3 ICT Impact on the Development of Company's Individual Elements

\begin{tabular}{|c|c|}
\hline $\begin{array}{l}\text { Company } \\
\text { element }\end{array}$ & Possible consequences of the implementation of ICT in the company \\
\hline Systems & $\begin{array}{l}\text { Development of a comprehensive integrated management information system } \\
\text { Redefining organizational procedures for the needs of the digital environment } \\
\text { Dissemination of telework }\end{array}$ \\
\hline Structure & $\begin{array}{l}\text { Transition from hierarchical structures to flat and network structures } \\
\text { Increasing role of self-organization and self-control staff } \\
\text { Redefining departments role - IT outsourcing }\end{array}$ \\
\hline Strategy & $\begin{array}{l}\text { Replacing strategic role of interest groups in the company's environment } \\
\text { Change in key drivers of competitive advantage } \\
\text { Shortening the product life cycle } \\
\text { New forms of economic cooperation } \\
\text { New variants of competitive strategies }\end{array}$ \\
\hline Styles of action & $\begin{array}{l}\text { Change in the nature of intellectual work } \\
\text { New model of communication } \\
\text { Dispersion of decision-making process } \\
\text { Increase in utilization of digital tools to support decision-making }\end{array}$ \\
\hline Personnel & $\begin{array}{l}\text { Extension working time } \\
\text { Increased psychological stress associated with work } \\
\text { Internet use for staff recruitment } \\
\text { Reduction in the importance of staff unions }\end{array}$ \\
\hline Values & $\begin{array}{l}\text { Facilitate the formation of the desired image and dissemination of the value of the } \\
\text { company } \\
\text { Promoting a culture of tasks within the company } \\
\text { Increasing the role of trust as a tool of control and coordination } \\
\text { Decreasing threat to data security } \\
\text { Construction of universal value systems }\end{array}$ \\
\hline Skills & $\begin{array}{l}\text { Need for continuous improvement of employees } \\
\text { Treating the Internet as a source of organizational knowledge } \\
\text { Change the nature of managerial work as a result of the acquisition of new } \\
\text { competencies by the company }\end{array}$ \\
\hline
\end{tabular}

Source: Nycz et al. 2015

From our point of view, the most important component of e-business enterprise, which has been changed under influence of ICT, is the management information system of a company. E-managers have to be informed about their business in general and about their area of responsibility in particular. Midway through the first decade of the $21^{\text {st }}$ century, the narrowly conceived idea of the MIS has become somewhat fuzzy. Management information systems, of course, are still doing their jobs, but their function is now one among many others that feed information to people in business to help them manage. Management information systems give the manager access to key data about his department and about the company in general.

Accounting is the main part of management information system. Therefore, its main purpose is providing complete, truthful and unbiased information about business activity for the users who can make relevant decisions based on this information. These decisions ensure that business entities run effectively in the present and will continue doing it in the future. In our 
opinion, accounting should develop at the same rules as management information system progress.

Based on a key part of management information system development, such as strategic planning and budgeting, accounting should improve as well. Management information systems contain past data for fundamental company functions such as sales, production and customer service. They include information on revenue, expenses and investments, broken down into separate components. A manager can look for trends by asking the systems to project past performance patterns into the future. Management information systems have sophisticated mathematical analysis tools that can evaluate relationships and calculate probable future trends (Inc., 2016). So management information systems, including accounting, should give needed information for decision making, taking into account external and internal environment of e-company. As a result, some approaches to accounting theory have to be changed (fig. 3).

Figure 3 Changes of Accounting in E-business Management Information System (Source: Inc. 2016)

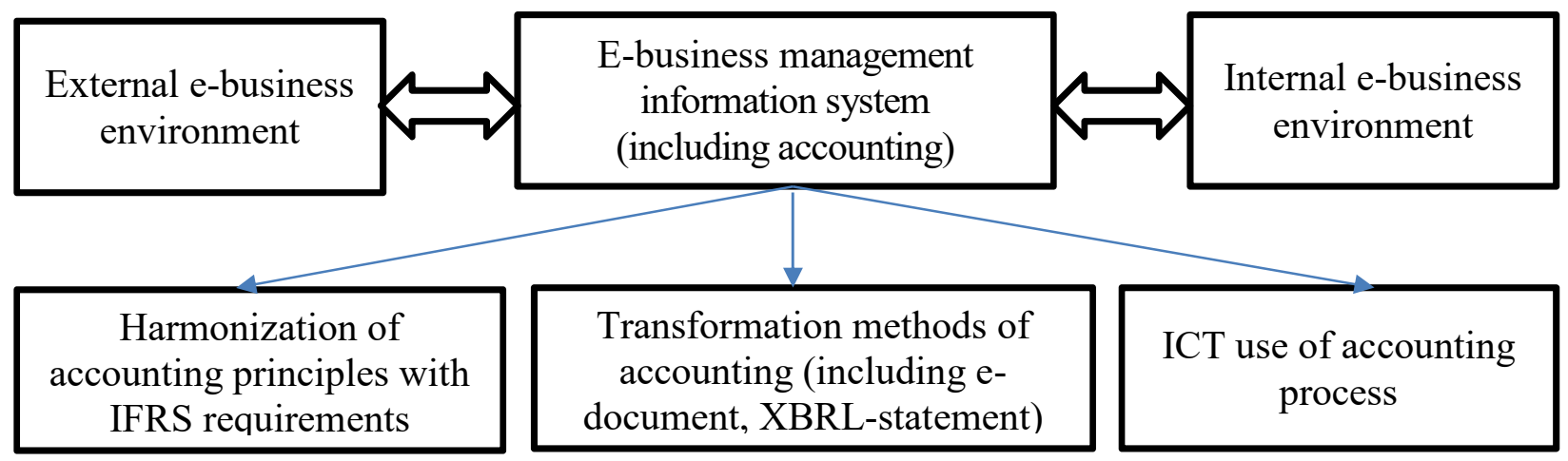

In our opinion, the experience of accounting organization in Belgium, Spain and Italy can be very useful for Ukrainian e-business enterprises. The means of accounting improvement used in these countries allow to reduce operating costs of e-business enterprises and to improve the efficiency of accounting system.

As of 2014, Belgium, the UK, France, the Netherlands, and Ireland were top five leading countries in Western Europe in terms of e-business turnover. Exploring the accounting experience at e-business enterprises in Belgium, the following information can be noted.

One of the main directions aimed at improvement of accounting in Belgium is the introduction of e-invoicing, which provides receiving and sending all invoices between counterparties digitally using integrated digital platforms. In particular, the study conducted by Poel et al. (2016) state that introduction of e-invoicing to the private sector saves a considerable amount of administrative costs for enterprises. The costs for preparing, sending and receiving invoices are a classic example of transaction costs, and costs related to the 
actual implementation of the agreement. According to this research, introduction of einvoicing should have a significant impact on tackling bureaucracy and, thus, reducing operating costs at companies.

In 2014, total annual cost of invoicing in Belgian private sector amounted to about 3.47 bn EUR ( $0.96 \%$ of GDP). This figure could be reduced to $1.46 \mathrm{mn}$ EUR $(0.38 \%$ of GDP) if all invoices were sent with integrated digital platforms. At the same time, the real savings from implementing e-invoicing are much lower than the potential ones.

Thus, the majority of managers at surveyed companies confirmed that e-invoicing reduced printing costs, provided more efficient information storage, and saved time required for its processing. However, a significant number of respondents have significant doubts concerning e-invoicing security. Moreover, it was supposed that creating and sending invoices by e-mail were more convenient and secure.

Apart from documentation improvement, the processes of grouping and summarizing accounting information should be transformed concerning modern information technologies. In this case, experience of Spanish enterprises can be used.

Spain is the leader in terms of e-business turnover within Southern European countries. As of 2014, the gross revenue in this sector was at 16.9 mn EUR. Apart from Spain, top five leading countries in Southern Europe (in terms goods and services sold online) include Italy, Turkey, Greece and Portugal.

The major direction towards improving the process of preparation, presentation and use of reporting is to carry out this process by using XBRL, which are accounting standards of information sharing. In Ukraine, the use of XBRL standards is planned to be implemented at the companies engaged in financial sector in 2018. At the same time, the necessity to apply XBRL standards by every single large enterprise, as well as the benefits that can be achieved as a result of the of XBRL standards introduction, have been provided in the study by Gonzálbez and Rodríguez (2012).

As regards small and medium enterprises, the need to use automated forms of processing accounting information is grounded in the research by Grande et al. (2011). The scientists have studied the efficiency of partial and complete automatization of accounting process for small and medium-sized companies. According to the research, partial automatization of accounting process is unprofitable and will not ensure competitive advantages for the enterprise.

All the changes in accounting system mentioned above illustrate new challenges, which top-managers and workers will have to cope with in the near future, and highlight new requirements for staff in e-business. 
Kulyk, V., Škodová Parmová, D.

\section{Skills required for professionals in digital economy and the development of educational system.}

Nowadays, society is at the early stage of the Fourth Industrial Revolution. The Fourth Industrial Revolution is a consequence of the Third Industrial Revolution, which used electronics and information technology to automate production. The main features of The Fourth Industrial Revolution is the fusion of technology and the "blurring of boundaries" between the physical, digital and biological spheres.

Features of the Fourth Industrial Revolution and its impact on modern society were the main topic of the world at the World Economic Forum in Davos in 2016. According to the results of the World Economic Forum, the Fourth Industrial Revolution will influence more than $35 \%$ of existing jobs. Numerous IT-technologies, such as robotics and autonomous transportation; artificial intelligence and machine training technologies; new materials and new achievements of biotechnology and genomics will be relevant and available by 2020 . Proceeding from this, some professions will disappear, some of them will be changed under IT-technology influence and many others will come to the future society.

However, underneath this aggregate outlook, there is once again significant relative growth in some job families and significant relative decline in others. For instance, some industries will need less labour force, such as reduction in Office and Administrative will consist 4,759 thousand employees during 2015-2020; Manufacturing and Production - 1,609 thousand employees. At the same time, some traditional industry will need more staff in the near future. For example, the rise in the number of employees in Business and Financial Operations will make up 492 thousand employees during 2015-2020; Management - 416 thousand employees; Computer and Mathematical - 405 thousand employees; Architecture and Engineering - 339 thousand employees; Sales and Related - 303 thousand employees; Education and Training - 66 thousand employees (WEF 2016, Chetverta promislova revolyuciya, 2016).

Therefore, people should obtain many new professional skills for being demanded at the future labour market. Today's workers should adapt to the changing environment and develop their skills in accordance with IT-progress while students should study in new conditions and get new abilities and skills.

Future needed abilities consist of two groups: Cognitive Abilities (Cognitive Flexibility; Creativity; Logical Reasoning; Problem Sensitivity; Mathematical Reasoning; Visualization) and Physical Abilities (Physical Strength; Manual Dexterity and Precision). The skills of future staff are divided into Basic Skills and Cross-functional Skills. Content Skills include Active Learning, such as Oral Expression; Reading Comprehension; Written Expression and 
ICT Literacy and Process Skills, which involve Active Listening; Critical Thinking; Monitoring Self and Others. Cross-functional Skills include Social Skills; Systems Skills; Complex Problem Solving Skills; Resource Management Skills and Technical Skills (WEF 2016, Chetverta promislova revolyuciya, 2016).

According to the other researches results, more than $47 \%$ kinds of profession which exist today will be fully automated in 20 years, and millions of employees will be unemployed (Chel, 2015). A University of Oxford report predicts that "by 2030, let alone by 2050, we'll have lost almost 50\% of the workforce to artificial intelligence" (Price, 2013).

The list of future jobs was highlighted in the World Economic Forum White Paper Digital Transformation of Industries: In collaboration with Accenture (table 4).

Table 4 Exemplary new job roles of the future

\begin{tabular}{|c|c|}
\hline Industry & Professions \\
\hline Commercial & $\begin{array}{l}\text { E-business manager } \\
\text { Digital account manager } \\
\text { Digital product manager } \\
\text { Digital business developer } \\
\text { Fraud manager }\end{array}$ \\
\hline Technology & $\begin{array}{l}\text { Scrum Master CDO (Chief Data Officer) } \\
\text { Data scientist } \\
\text { Data protection officer } \\
\text { Traffic manager }\end{array}$ \\
\hline Web & $\begin{array}{l}\text { Web project manager } \\
\text { Webmaster } \\
\text { Web designer } \\
\text { Web integrator } \\
\text { Developer } \\
\text { SEO manager }\end{array}$ \\
\hline Marketing & $\begin{array}{l}\text { Digital marketing professional/Micro marketing } \\
\text { Digital communications manager/Digital planner SEM/PPC manager } \\
\text { Digital copywriters } \\
\text { Media acquisition manager } \\
\text { User experience designer }\end{array}$ \\
\hline Facilitation & $\begin{array}{l}\text { Service design thinker } \\
\text { Crowd innovation facilitator/Fabmanager Community manager/ social media } \\
\text { manager } \\
\text { Editorial manager } \\
\text { Content curator } \\
\text { Chief listening officer }\end{array}$ \\
\hline $\begin{array}{l}\text { Human } \\
\text { Resources }\end{array}$ & $\begin{array}{l}\text { Design learning manager } \\
\text { Digital work experience expert } \\
\text { Employer brand director (including social media strategist) }\end{array}$ \\
\hline
\end{tabular}

Source: WEF 2016

This information motivated scientists to research the problems connected with decrease in the importance of the current humanity as a huge labour force. One of them is low computer 
literacy rate of a large part of the world's population, including the lack of access to the Internet worldwide and ICT-knowledge and skills. This problem is extremely topical in African countries and in Asia partially, which have the highest population growth on the planet.

At the same time, the largest number of Internet users comes from developed countries. They are 15-24-year olds with the experience of network use for over 5 years. People in this age group, are also called generation "X". These individuals were born after 1980 and reached adulthood in the new Millennium. They are more likely to use and create online materials and evaluate their innovative and creative abilities on the higher level. Moreover, network technologies are changing their way of thinking and ways of understanding information. Generation "X" will make up 75\% of the global labour force by 2025 . The hallmark of this generation is that it was the first of the younger digital generation. A significant part of their activities, including socializing and knowledge management is carried out by means of digital technologies (UNCTAD, 2015).

Therefore, a high level of computer literacy is a prerequisite for employment in the future. However, the rapid development of ICT technology worldwide will determine numerous changes of workplace organization, which are important for employers and employees. There are some of the potential options of future labour market, which should be taken into account (table 5).

Table 5 Workplace Development under Influence of ICT by the Year 2050

\begin{tabular}{|l|l|}
\hline \multicolumn{1}{|c|}{ Aspect } & \multicolumn{1}{|c|}{ Comments } \\
\hline $\begin{array}{l}\text { 1. "Corporation ladder" } \\
\text { will turn into } \\
\text { "Corporation network" }\end{array}$ & $\begin{array}{l}\text { Over the past 25 years, Every fourth company began transition from a } \\
\text { vertical to a horizontal hierarchy, reducing a significant part of } \\
\text { management levels. This not only helps to reduce salary costs, but also } \\
\text { reduces performance. } \\
\text { On the one hand, ordinary employees do not have prospects for career } \\
\text { growth. On the other hand, the absence of managers help to solve the } \\
\text { problem of inequality of salaries }\end{array}$ \\
\hline $\begin{array}{l}\text { 2. Artificial intelligence } \\
\text { will replace people in } \\
\text { many jobs }\end{array}$ & $\begin{array}{l}\text { Experts from Oxford studied all industries, where employees have a risk to } \\
\text { lose their jobs. This list includes many industries, such as transportation } \\
\text { and logistics, because now unmanned vehicles are developed and } \\
\text { implemented there and school teacher, despite the fact that this profession } \\
\text { needs direct human participation (Canton 2015). }\end{array}$ \\
\hline $\begin{array}{l}\text { 3. New professions will } \\
\text { emerge as a result of the } \\
\text { robotization of economy }\end{array}$ & $\begin{array}{l}\text { In the future, humans and robots will work together. The representatives of } \\
\text { new professions will control robots by artificial intelligence. Workers } \\
\text { owning the "old" professions, will perform work under the robot-managers }\end{array}$ \\
\hline $\begin{array}{l}\text { 4. Employers can refuse } \\
\text { from staff and will find } \\
\text { the staff among } \\
\text { freelancers }\end{array}$ & $\begin{array}{l}\text { Using the work of freelancers will be very popular among employers. This } \\
\text { approach to the use of labour force saves money of companies. For } \\
\text { workers, freelancing is the ability to work at flexible hours from any point } \\
\text { of the globe. Feature of freelancing is the lack of medical and social } \\
\text { insurance }\end{array}$ \\
\hline
\end{tabular}


Table 5 (continued)

\begin{tabular}{|c|c|}
\hline Aspect & Comments \\
\hline $\begin{array}{l}\text { 5. The lack of pension } \\
\text { insurance }\end{array}$ & $\begin{array}{l}\text { Life expectancy is constantly growing; so many people have to work to } \\
\text { the logical conclusion of their lives. At the same time, the younger } \\
\text { generation has no opportunity to accumulate savings for the future } \\
\text { through the failures of the financial system and the crisis phenomena in } \\
\text { the economy. The positive thing in this situation is that the latest } \\
\text { achievements in medicine will help people to have good health for long } \\
\text { time }\end{array}$ \\
\hline $\begin{array}{l}\text { 6. Employees will } \\
\text { increase the requirements } \\
\text { for employers and more } \\
\text { likely to change jobs }\end{array}$ & $\begin{array}{l}\text { The concept of "one life, one profession" recedes into the past. Workers } \\
\text { will change jobs, "on call of their hearts". Social responsibility and moral } \\
\text { principles of top-managers will be an important criterion in choosing a } \\
\text { workplace }\end{array}$ \\
\hline $\begin{array}{l}\text { 7. Employees will be } \\
\text { under the close control of } \\
\text { the employer, even in } \\
\text { their free time }\end{array}$ & $\begin{array}{l}\text { In future employers will be able to monitor and track their employees to a } \\
\text { higher level. The sensors will transmit information about their location, } \\
\text { performance and health }\end{array}$ \\
\hline $\begin{array}{l}\text { 8. Companies will } \\
\text { abandon from the } \\
\text { traditional offices and } \\
\text { headquarters }\end{array}$ & $\begin{array}{l}\text { Coworking is becoming more popular not only among freelancers and } \\
\text { entrepreneurs, but also among corporations. Coworking center will } \\
\text { become the places, where they will accommodate its employees. } \\
\text { Abandoning of the traditional system of offices and headquarters will } \\
\text { allow companies to hire the best candidates worldwide, regardless of how } \\
\text { far they are from the main office }\end{array}$ \\
\hline $\begin{array}{l}\text { 9. The use of autonomous } \\
\text { cars will help faster and } \\
\text { easier to get to the } \\
\text { workplace }\end{array}$ & $\begin{array}{l}\text { On the one hand, unmanned vehicles will capable to provoke a wave of } \\
\text { mass layoffs of current employees in the transport industry. On the other } \\
\text { hand, unmanned vehicles will help solve the problem of morning traffic } \\
\text { jams and reduce the number of accidents }\end{array}$ \\
\hline
\end{tabular}

Source: Stanger 2016.

Therefore, the generalized list of professional skills, aiming on the creation future successful workforce, was compiled by researchers of Institute for the Future (IFTF). There are ten professional skills, which will be needed by 2020 and six drivers, which are important in shaping the landscape in which each skill emerges, and include following:

1) extreme longevity - increasing global lifespans change the nature of careers and learning;

2) rise of smart machines and systems - workplace automation nudges human workers out of rote, repetitive tasks;

3) computational world - massive increases in sensors and processing power make the world a programmable system;

4) new media ecology - new communication tools require new media literacies beyond text;

5) superstructed organizations - social technologies drive new forms of production and value creation;

6) globally connected world - increased global interconnectivity puts diversity and adaptability at the centre of organizational operations (table 6). 
Table 6 Future Work Skills 2020

\begin{tabular}{|c|c|c|}
\hline Skill & $\begin{array}{l}\text { Driver, which is } \\
\text { important in shaping } \\
\text { of each skill emerge }\end{array}$ & Comments \\
\hline SenseMaking & $\begin{array}{l}\text { Rise of smart } \\
\text { machines } \\
\text { systems }\end{array}$ & $\begin{array}{l}\text { That skill involves the ability to understand the } \\
\text { deep meaning and significance of the information } \\
\text { that people try to convey. At this stage of the } \\
\text { development of technology, machines cannot } \\
\text { understand the meaning of information that is } \\
\text { processed by them. Currently, no robot can replace } \\
\text { a human's ability to generate specific ideas, to } \\
\text { come to certain conclusions and have a critical } \\
\text { approach to information when decisions are made }\end{array}$ \\
\hline $\begin{array}{l}\text { Novel and Adaptive } \\
\text { Thinking }\end{array}$ & $\begin{array}{lr}\text { Rise of } & \text { smart } \\
\text { machines } & \text { and } \\
\text { systems } & \\
\text { Globally } & \text { connected } \\
\text { world } & \end{array}$ & $\begin{array}{l}\text { Situational adaptability - the ability to respond to } \\
\text { unique unexpected circumstances. In the future, } \\
\text { employees who are able at the right time to go } \\
\text { beyond not lose; even in the most difficult situation } \\
\text { will be needed indeed. Employees who have well- } \\
\text { developed social and emotional intelligence can } \\
\text { feel the mood of others, to cause the desirable } \\
\text { reactions of people }\end{array}$ \\
\hline Social Intelligence & $\begin{array}{lr}\text { Rise of } & \text { smart } \\
\text { machines } & \text { and } \\
\text { systems } & \\
\text { Globally } & \text { connected } \\
\text { world } & \end{array}$ & $\begin{array}{l}\text { Despite the presence of "social" and "emotional" } \\
\text { prototypes among robots, they do not possess the } \\
\text { necessary social skills and needed level of emotion } \\
\text { to replace human beings. Employees, who have } \\
\text { well-developed social and emotional intelligence } \\
\text { will have a big competitive advantage in the future. } \\
\text { People who can feel others' mood, to cooperate } \\
\text { with different people will have a great demand in } \\
\text { the labour market }\end{array}$ \\
\hline $\begin{array}{l}\text { Cross } \\
\text { Competency }\end{array}$ & $\begin{array}{l}\text { Superstructed } \\
\text { organizations } \\
\text { Globally connected } \\
\text { world }\end{array}$ & $\begin{array}{l}\text { In the context of globalization, employees must be } \\
\text { able to work anywhere in the world. Cross Cultural } \\
\text { Competency provides successful cooperation with } \\
\text { representatives of various cultures and } \\
\text { nationalities. This skill is necessary not only for the } \\
\text { employees, who will work abroad, but also for } \\
\text { workers, who will perform their professional duties } \\
\text { within a country. Due to the fact that a close } \\
\text { cooperation between different age and national } \\
\text { groups is considered by corporations as a potential } \\
\text { source of innovation for the enterprise as a whole. } \\
\text { The combination of people belonging different } \\
\text { nationalities and age groups in one team is one of } \\
\text { the ways to increase of business efficiency }\end{array}$ \\
\hline Virtual Collaboration & $\begin{array}{l}\text { Superstructed } \\
\text { organizations } \\
\text { Globally connected } \\
\text { world }\end{array}$ & $\begin{array}{l}\text { In the future, to be successful, all employees will } \\
\text { need to learn how to work productively as a } \\
\text { member of virtual team. The company will have } \\
\text { not only to build effective production processes, } \\
\text { but also to learn how to attract and motivate } \\
\text { employees at a distance. Gamification is one of the } \\
\text { main ways of development workplace. Taking into } \\
\text { account these changes, members of virtual work } \\
\text { teams, should care how work productively and } \\
\text { efficiently outside of the classic office }\end{array}$ \\
\hline
\end{tabular}


Table 6 (continued)

\begin{tabular}{|c|c|c|}
\hline Skill & $\begin{array}{l}\text { Driver, which is } \\
\text { important in shaping } \\
\text { of each skill emerge }\end{array}$ & Comments \\
\hline Design Mindset & $\begin{array}{l}\text { Superstructed } \\
\text { organizations } \\
\text { Computational world }\end{array}$ & $\begin{array}{l}\text { Sensors and other telecommunication gadgets will } \\
\text { bring new opportunities in the development of our } \\
\text { work organization. Future workers should become } \\
\text { an expert in the recognition of the type of thinking } \\
\text { their conversational partners. Moreover, people } \\
\text { need to learn how to filter information, using all the } \\
\text { technological achievements and develop their own } \\
\text { means to cope with the information "noise" to } \\
\text { manage all information flows effectively }\end{array}$ \\
\hline $\begin{array}{l}\text { Cognitive } \\
\text { Management }\end{array}$ & $\begin{array}{l}\text { Superstructed } \\
\text { organizations } \\
\text { Computational world } \\
\text { New media ecology }\end{array}$ & $\begin{array}{l}\text { Cognitive load management is the ability to } \\
\text { discriminate and filter the most important } \\
\text { information exceptionally. Nowadays, often feel } \\
\text { overwhelmed. Future workers should learn how to } \\
\text { make decisions taking into account a huge amount } \\
\text { of information. This skill needs to be developed } \\
\text { because the amount is rising constantly }\end{array}$ \\
\hline New Media Literacy & $\begin{array}{l}\text { Extreme longevity } \\
\text { Computational world } \\
\text { New media ecology }\end{array}$ & $\begin{array}{l}\text { New media literacy is the ability to evaluate the } \\
\text { content of different sources of information } \\
\text { critically. This ability includes using new media- } \\
\text { opportunities for persuasive communication. Blogs, } \\
\text { social networks, forums are important spheres for } \\
\text { collabouration among consumers and will become } \\
\text { field for professional skills applications. Future } \\
\text { employees should know how to create and post } \\
\text { text, audio and video content in the modern forms } \\
\text { of media and communication }\end{array}$ \\
\hline $\begin{array}{l}\text { Computational } \\
\text { Thinking }\end{array}$ & $\begin{array}{l}\text { Computational world } \\
\text { New media ecology }\end{array}$ & $\begin{array}{l}\text { The amount of data that we process every day is } \\
\text { increasing exponentially. The ability to understand } \\
\text { all this information and summarize it is other } \\
\text { important skill in the future career. At the same } \\
\text { time, employees should not rely on data } \\
\text { exceptionally. Workers should often make } \\
\text { decisions and act when the information for decision } \\
\text { making is missed }\end{array}$ \\
\hline Transdisciplinarity & $\begin{array}{l}\text { Extreme longevity } \\
\text { Computational world }\end{array}$ & $\begin{array}{l}\text { Many of companies require interdisciplinary } \\
\text { solutions for their development and growth. The } \\
\text { ideal employee in the future has specialization in } \\
\text { some field and has good knowledge in other related } \\
\text { fields, needed to talk to specialists of other areas on } \\
\text { the "same language" }\end{array}$ \\
\hline
\end{tabular}

Source: Davies et al. 2011

Later, this list was completed by four new skills, such as: self-motivation; time management; management of own incomes; online PR-management. It can be seen that all needed skills are connected not only with some particular kind of knowledge, but also with social and emotional spheres of human life. Therefore, many scientists researches different means of including social and emotional education into curricula. 
To prove of necessary of social and emotional learning (SEL), other group of scientists highlighted more wide lists of professional skills. Coupled with mastery of traditional skills, social and emotional proficiency will equip students to succeed in the swiftly evolving digital economy. According to the near researches, 16 crucial proficiencies for education in the $21 \mathrm{st}$ century were defined. Those skills include six "foundational literacies", such as literacy, numeracy and scientific literacy, and 10 skills that we labelled either "competencies" or "character qualities". Competencies are the means by which students approach complex challenges; they include collaboration, communication and critical thinking and problemsolving. Character qualities are the ways in which students approach their changing environment; they include curiosity, adaptability and social and cultural awareness (WEF, 2016).

Given current trends in the development of the information economy, members of the international community noted that for people who are currently working in various sectors of the economy is needed the "lifelong learning" approach in education and for pupils and students need the transformation of the education system.

Incentivizing lifelong learning should be important part of government policy. The dwindling future population share of today's youth cohort in many ageing economies implies that simply reforming current education systems to better equip today's students to meet future skills requirements - as worthwhile and daunting as that task is - is not going to be enough to remain competitive. Ageing countries won't just need lifelong learning-they will need wholesale reskilling of existing workforces throughout their lifecycle. Governments and businesses have many opportunities to collaborate more to ensure that individuals have the time, motivation, and means to seek retraining opportunities (WEF, 2016).

By one popular estimate $65 \%$ of children entering primary schools today will ultimately work in new job types and functions that currently don't yet exist. Technological trends such as the Fourth Industrial Revolution will create many new cross-functional roles for which employees will need both technical and social and analytical skills. Most existing education systems at all levels provide highly siloing training and continue a number of 20th century practices that are hindering progress on today's talent and labour market issues. Businesses should work closely with governments, education providers and others to imagine what a true 21 st century curriculum might look like (WEF, 2016).

The challenges of the modern economy, which is changing constantly, influence on the learning approaches in various educational institutions. The teachers of the University of South Bohemia have considerable experience in the formation of specialists for a new type of economy. Their achievements in the methods of teaching of economic courses can be applied in higher educational institutions of Ukraine. 


\section{Application of the European Union and the Czech Republic experiences in development of Ukrainian e-business and Ukrainian education system.}

ICT industry is developed enough in the Czech Republic because the government is sure that this industry can become a driver for Czech economy at whole. There are many indicators, which demonstrate development of IT-sector in the Czech Republic and make this country attractive for foreign investors.

The Czech Republic is one of Europe's top locations for ICT investments. Repeatedly recognized by various researchers, this fact is confirmed by the strong inflow of high-valueadded projects of the world's top ICT companies and is fuelled by the country's tradition of excellence in technical fields. The list of successful investors in the country involves Microsoft, Skype, DHL, Tieto, Red Hat, SolarWinds and IBM. Two of the world's few antivirus-software providers, AVAST and AVG, grew out of this environment (Discover ICT, 2015).

This favourable environment, which was created in the Czech Republic, allowed to develop different sectors of economy, such as e-business and education sphere. In this research, we generalized positive aspects, which exist in the Czech Republic concerning ITsector and related spheres for using Czech experience in Ukraine.

Table 7 The Czech Republic Experience in IT-sector

\begin{tabular}{|c|c|}
\hline Aspect & Czech experience \\
\hline $\begin{array}{l}\text { The Czech } \\
\text { Republic is one } \\
\text { of Europe's top } \\
\text { locations for } \\
\text { ICT } \\
\text { investments }\end{array}$ & $\begin{array}{l}\text { 1. The Czech Republic is the only country using the Latin alphabet where Google is } \\
\text { not number one on the Internet as the Czech web search provider Seznam.cz is } \\
\text { locally dominant. } \\
\text { 2. Thanks to investments in infrastructure other Czech regions other than Prague } \\
\text { are gaining attractiveness, especially in the ICT sector. } \\
\text { 3. The Czech Republic's ICT-friendly policies and skilled workforce, good } \\
\text { infrastructure and well-developed optical-fibre network make it the most prominent } \\
\text { location in the CEE region in terms of the ICT field }\end{array}$ \\
\hline $\begin{array}{l}\text { ICT Related } \\
\text { Education }\end{array}$ & $\begin{array}{l}\text { The Czech Republic combines an outstanding level of general education with } \\
\text { strong science and engineering disciplines. } \\
\text { Universities offer programs ranging from ICT to life sciences. University education } \\
\text { is generally focused on meeting the needs of a competitive economy, and } \\
\text { cooperation between universities and the corporate sector has been expanding in } \\
\text { recent years }\end{array}$ \\
\hline $\begin{array}{l}\text { Labour } \\
\text { Availability and } \\
\text { Skills }\end{array}$ & $\begin{array}{l}\text { The Czech Republic offers a large number of skilled technical workers. The } \\
\text { country's well-deployed education system can serve as a basis for future skills } \\
\text { development and contributes to the development of the sector. } \\
\text { The wage amount always depends on the level of education, specialization and } \\
\text { level of experience, as well as on the size of the given company }\end{array}$ \\
\hline
\end{tabular}


Table 7 (continued)

\begin{tabular}{|c|c|}
\hline $\begin{array}{l}\text { Research and } \\
\text { Development } \\
\text { Centres }\end{array}$ & $\begin{array}{l}\text { IT4Innovations carries out research mainly in the fields of supercomputing and } \\
\text { embedded systems. In addition to research, the centre, as the national HPC e- } \\
\text { infrastructure, operates unique state-of-the-art supercomputing resources and } \\
\text { makes them available to Czech and foreign research teams from academia and } \\
\text { industry } \\
\text { CERIT Scientific Cloud (CERIT-SC) the CERit-SC centre is one of the three } \\
\text { essential parts of the national e-infrastructure, a complex system of mutually } \\
\text { interconnected network, computing, and storage resources and corresponding } \\
\text { services for the Czech research community } \\
\text { Czech Education and Scientific NETwork (CESNET) CESNEt, its main goals are } \\
\text { operation and development of the Czech National Research and Education } \\
\text { Network (NREN), research and development of advanced network technologies } \\
\text { and applications and broadening of the public's knowledge of advanced } \\
\text { networking topics. } \\
\text { SIX Research Centre the Centre of Sensor, information and Communication } \\
\text { Systems (SiX) was established to provide comprehensive research and } \\
\text { development services in the area of wireless communication. } \\
\text { NTIS New technologies for the information Society (NtiS) is a modern research } \\
\text { centre, its activities are focused on the development of cybernetics, computer } \\
\text { science, mechanics, physics, mathematics and geomatics }\end{array}$ \\
\hline Company Focus & $\begin{array}{l}\text { AVG is an online security company providing leading software and services for } \\
\text { the purpose of securing devices, data and people } \\
\text { AVAST is one of the pioneers in the computer security business, with a portfolio } \\
\text { that includes free antivirus applications for PC, Mac and Android, as well as } \\
\text { premium suites and services for both consumers and business. in addition to being } \\
\text { top-ranked by consumers on popular download portals worldwide }\end{array}$ \\
\hline Avast enthusiasts & $\begin{array}{l}\text { Today Seznam.cz reaches approximately } 90 \% \text { of the Czech internet population. } \\
\text { this means that at least once a month almost every one of the six million Czechs } \\
\text { who use the internet in the Czech Republic uses some of the services that } \\
\text { Seznam.cz offers } \\
\text { Red Hat Red Hat is the world's leading provider of open-source software } \\
\text { solutions, using a community- powered approach to reliable and high-performance } \\
\text { cloud, Linux, middleware, storage and virtualization technologies. Red Hat also } \\
\text { offers award-winning support, training and consulting services. } \\
\text { MSD is a global healthcare leader working to help the world be well. through its } \\
\text { prescription medicines, vaccines, biological therapies and animal health products, } \\
\text { MSD works with customers and operates in more than } 140 \text { countries to deliver } \\
\text { innovative health solutions }\end{array}$ \\
\hline Selected Clusters & $\begin{array}{l}\text { Safety \& Security Technology Cluster } \\
\text { This cluster focuses primarily on activities in the fields of research, development } \\
\text { and innovation, marketing and promotion, while strengthening the links between } \\
\text { members and supporting activities leading to effective training and development } \\
\text { of the cluster members' staff } \\
\text { http://www.btklastr.cz/en/ } \\
\text { Czech Cloud Cluster } \\
\text { This cluster's mission is to increase the competitiveness and economic growth of } \\
\text { entrepreneurs in the fields of big data and iCt services www.czechcloudcluster.cz } \\
\text { Czech IT Cluster } \\
\text { This cluster comprises mainly small and medium-sized companies in the field of } \\
\text { information technology, educational institutions, and a range of partner } \\
\text { organizations } \\
\text { www.czech-itc.cz }\end{array}$ \\
\hline
\end{tabular}


Table 7 (continued)

\begin{tabular}{|c|c|}
\hline Selected Clusters & $\begin{array}{l}\text { Hradec IT Cluster } \\
\text { The objective of the Hit Cluster is to provide services for its members to jointly } \\
\text { improve the quality of management, increase innovation potential, save costs and } \\
\text { to develop business possibilities in the areas of human resources development, } \\
\text { marketing, sharing of capacities, technological development and innovations. the } \\
\text { applicability of new technologies includes distributed backup environments, } \\
\text { automation of information system management, information system security and } \\
\text { server housing (server virtualization, application clustering, geographical backup) } \\
\text { www.hitklastr.cz } \\
\text { IT Cluster } \\
\text { The IT Cluster's core activities include research projects in the areas of software } \\
\text { service quality, it service management, research and development in wireless and } \\
\text { mobile technologies (using the potential of } 3 \mathrm{G} \text { networks and developing } \\
\text { Intelligent Traffic Systems) } \\
\text { www.itcluster.cz } \\
\text { Network Security Monitoring Cluster } \\
\text { The Network Security Monitoring Cluster is a leading organization in network } \\
\text { security in the CEE region. its mission is to create a centre of excellence in the } \\
\text { field of computer network security } \\
\text { www.nsmcluster.com }\end{array}$ \\
\hline $\begin{array}{l}\text { Professional } \\
\text { Groups }\end{array}$ & $\begin{array}{l}\text { Czech ICT Alliance Members of the Czech ICT Alliance are significant } \\
\text { multinational companies operating in the Czech Republic (e.g. Ness) and leading } \\
\text { Czech firms (e.g. Unicorn, LCS) as well as a range of small and medium-sized } \\
\text { Czech companies with extensive international ambitions. the alliance currently } \\
\text { has } 20 \text { members, but thanks to the scope of its activities, it has helped dozens of } \\
\text { Czech IT firms with foreign expansions. } \\
\text { ICT Unie iCt Unie is an professional association of companies in the iCt sector, } \\
\text { other business and educational entities that aims to raise awareness of the } \\
\text { importance of innovating and using modern information technology and } \\
\text { electronic communication in society, including the creation of optimal conditions } \\
\text { for the development of the iCt infrastructure in the Czech Republic, as a } \\
\text { prerequisite for the development of the information society. } \\
\text { AFI the Association for Foreign investment (AFi) represents a group of service } \\
\text { companies with local experience that support the entry of foreign investors into } \\
\text { the Czech Republic and offer a wide range of professional services to foreign } \\
\text { investors entering the local market. } \\
\text { CzechInvest's Services. Objectives of CzechInvest's Services are to advise and } \\
\text { support existing and new companies and foreign investors in the Czech Republic; } \\
\text { to support the competitiveness of the Czech economy; to create a space for } \\
\text { communication between foreign investors, the state administration and Czech } \\
\text { companies }\end{array}$ \\
\hline
\end{tabular}

Source: CzechInvest 2016

If we look at all these aspects of IT-sector in the Czech Republic, it can be seen that Ukraine may use many of them for Ukrainian IT-sector development. In our opinion, the most important of them:

1) improvement of investment climate, in IT-sector, particularly. There are some particularities in Ukrainian investment climate. The advantages are developed human capital; higher level of investment return than in developed countries; transit position of the country. 
The disadvantages consist of low institutional level of development, bureaucracy; unstable politic situation; corruption;

2) support to IT-related education. Nowadays, Project of the European education initiative started in January 2016 in Ukraine. The project aims at the development of education and the integration of global best practices in system training for professionals. The project's goal is to provide everyone who wants quality and modern education in the field information technologies, help IT professionals to be competitive and guaranteed employed. In terms of cooperation with universities, this project consist following: grants and scholarships for students of it specialties; professional certification and testing of students for compliance with professional it standards the requirements of it companies to it professionals; integration certified training centres of information technology in the educational process of educational institutions; financial support of higher education institutions of project partners from the it business; graduates (The Council on competitiveness ICT industry, 2016);

3) appropriate tax regulation for IT-companies and E-business. Ukrainian legislation is changing permanently, this situation has negative influence on invest climate in Ukraine and e-business development within Ukraine;

4) support to Research and Development Centres and creation IT- clusters in Ukraine. There are five IT-cluster in Ukraine, in Cherkasy, Kharkiv, Lutsk, Lviv and Odessa. They work with participation of IT-companies, e-business companies, educational institutions and local authorities. At the same time, it is too earlier to speak about great results of them.

Despite the fact that the level of collaboration in IT-sector is not too high, cross-industry and public-private collaboration is a perspective way of economic development.

Businesses should work with industry partners to develop a clearer view on future skills and employment needs, pooling resources where appropriate to maximize benefits, and work more closely with governments to map a future view of skill demand versus supply. While a single business can form one-to-one partnerships for its own talent needs, partnerships between multiple businesses, educational institutions and accreditation providers can result in an overall increase in the quality of the talent pool, at lower costs and with greater social benefits. Businesses also need to engage with governments on strategically redeploying redundant skills between sectors, addressing cost concerns and social stability (WEF, 2015).

The growing role of business virtualization needs the changes of professional skills. These changes should touch all participants in e-business, both employers and employees. Many Ukrainian universities already have curricula items with "E-commerce" and "E-business" issues, such as Poltava University of Economics and Trade. 


\section{DISCUSSION AND CONCLUSION}

Based on the information presented in this research, the problems of university education at ebusiness sphere should be considered. Because students, who will work at virtual enterprises in the near future, should be ready for many new challenges, which are involved e-business (table 8).

Table 8 Advantages and Disadvantages of the Virtual Form of Work

\begin{tabular}{|c|c|}
\hline \multicolumn{2}{|c|}{ Advantages } \\
\hline Employer & Worker \\
\hline Flex staffing & Flexibility of hours \\
\hline Reduced overhead & Work remotely \\
\hline No benefits & Variable work Variety \\
\hline Scale & More opportunities \\
\hline Improved margin & Projects you choose \\
\hline Specialty expertise as needed & Less job discontentment \\
\hline No labour unions & Self-employment \\
\hline Variable labour model & \\
\hline \multicolumn{2}{|c|}{ Disadvantages } \\
\hline Employer & Worker \\
\hline No loyalty & Limited job security \\
\hline Less retention & Minimal benefits \\
\hline Lost domain knowledge & Cyclical wages \\
\hline Challenging social aspects & Less career advancement \\
\hline
\end{tabular}

Source: Houlne 2013.

If we look at educational system in Ukraine, some obstacles could be seen, which inhibit of obtaining, needed professional skills by students, who will work in digital economy.

First of all, to obtain these needed skills, students should get an appropriate level of training during their studying at university. At the same time, Ukrainian universities may not offer their potential students high level of educational services at e-business field, because they have some issues at educational process. For example, teachers of universities do not know English enough and it becomes the main problem in educational process because they cannot use the latest achievements in scientific and practice fields and share with them with their students. So, students should find out this information from different sources.

Besides that, students do not get some real practice experience during their studies at universities. So, they have big problems when they start looking for job after graduation. In addition, a difficult economic situation has negative influence at the students. Traditionally, in Ukraine parents pay for the university and subsidize their children for five years of education. In current economic situation, many parents cannot do it anymore. In this case, many potential students refuse from university education and start working. In our opinion, it may be good if they can possibility to study and work at the same time.

One of the ways to solve these problems is the creation of educational clusters. On the one hand, it is very important to have well-known brand of university or academy and to prove 
that students of a particular university are better than students of other universities or academies daily. Unfortunately it is necessary, because branding is the main way of attracting students who are the key financial source for the universities now. One the other hand, all economic institutions in Poltava region have the same challenges to overcome. Some of them are real, some of them are delusive but many potential students and their parents, who invest money in their children education, have special points of view about education.

One of the most striking features of this problem is that many people in the Ukraine claim that: 1) potential students often should choose educational institutions in cities or other countries because they think that the quality of education is better there; 2) potential students know that the situation at the labour market is better in cities and foreign countries; 3) life and work in cities and foreign countries are more interesting, vibrant and can give more possibilities in their future.

To address these issues universities have to: 1) improve the level of educational services in particular regions. To reach (For reaching) this, education institutions should create conditions aimed at the development of teachers' professional skills, foreign language skills, research skills and so on; 2) help their students to get real experience in operating enterprises; all trainings should be real; 3) develop curricula which would include courses that may help students to create their own business in different industries; 4) give possibilities to study in foreign countries during their study at regional universities.

Tackling these issues can be reached by cooperation, some common projects might be: 1) creation of a linguistic centre to improve knowledge of English among teachers of universities. This centre should have not only educational purpose, but also certify its students and help teachers to translate their scientific researches; 2) creation of a data-base centre for spreading the results of scientific research abroad. This centre should give teachers an access to different data-bases and provide information about different scientific journals where their research can be published; 3) creation of a centre of international cooperation, which should accumulate and provide information about perspective grant programs available for teachers and students and the offers from foreign partner-universities; 4) creation of a centre of business planning, which can help teachers and students to run their own business or get earnings as freelancers. This centre should track information about the latest business trends, which do not need big investments and present it for teachers and students. As reported by Molnár and Vancsik (2016) human resources are the most important in the development of companies. 
All these things may be done easily in conditions of cooperation between universities. However, it is difficult to solve these issues because in this situation the universities should stop being competitors in the same fields. Therefore, we can say beyond any doubt that creation of educational clusters in regions would generate many benefits, such as: 1) higher level of educational services in the region; 2) closer (better) international cooperation; 3) the use of new interesting forms of study; 4) the development of business in the region.

\section{SUMMARY}

E-business is, without any doubt, a leading trend in the world. E-business is a new kind of business that is run with the use of ICT-technology and the Internet. E-business is developing very rapidly worldwide. Ebusiness integrates all components of modern society and changes the existing business model. All ebusiness companies are influenced by components of the external environment, which includes: 1) Country Characteristics; 2) Government Dimension; 3) Business Dimension; 4) Technology Dimension. For the successful functioning of e-business enterprises and the achievement of their strategic objectives, managers have to manage the components of the internal environment of the enterprise, e-business, which include: 1) Product; 2) Customer Interface; 3) Infrastructure Management; 4) Financial Aspects.

For being a part of the EU Digital Single Market, Ukraine needs to change its legislation in accordance with the EU legislation. This step will allow Ukraine to attract investments in Ukrainian IT-sector and provide an opportunity for Ukrainian e-business companies to work in the EU. The key fields that need be considered in the process of establishing a legal framework for e-business are the following: data protection; a safe form of a contract in legal and commercial sense; the electronic signature; consumer protection; e-privacy; computer crime prevention; intellectual rights; the regulations of the contents posted on the Internet; a law on the free access to information; a law on personal information protection. Also, in the European Union member states, e-business has contributed to the social and economic development of the region. One of the main way of that is the creation of IT-clusters.

The EU encourages such initiatives and shares the examples of best practices. It is necessary to raise awareness of the advantages of e-business at all levels of society, provide appropriate telecommunication infrastructure, provide support to e-business companies and their associations, take an active participation in the IT-education promotion and create a solid legal environment for e-business. As a result, Ukrainian e-business will become more developed and all participants' goals will be achieved.

Besides that as the share of e-business enterprises in Ukraine tends to increase, the implementation of the following means concerning accounting improvement can take place: 1) e-invoicing should be used by all kinds of e-business enterprises; 2) XBRL (extensible business reporting language) has to be implemented by all large e-business enterprises; 3 ) small and medium-sized companies need rely on fully automatized accounting processes in its activities.

\section{Acknowledgments}

This paper is based upon a work supported by the International Visegrad Fund under the Scholarship program Contract No. 51602000.

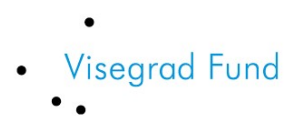

\section{REFERENCES}

Admit, R., Zott C. (2001). Value creation in e-business. Strategic Management Journal, 22, 493-520.

APEK (2016). Česká e-komerce v roce 2015 předčila očekávání, růst se nezastaví ani v roce 2016 (Czech e-commerce in 2015 exceeded expectations, growth does not stop even in 2016).- Access from: https://www.apek.cz/clanky/ceska-e-komerce-v-roce-2015predcila-ocekavani-ru

Beynon-Davies, P. (2007). E-business Maturity and Regional Development. International Journal of Business Science and Applied Management, vol. 2, issue 1, 9-20. 
Canton, J., (2015). Future Smart: Managing the Game-Changing Trends that Will Transform Your World Hardcover, Da Capo Press, 400.

Chaston, I., Mangles, T., (2002). E-commerce in small US manufacturing firms: a pilot study on internal competencies. Journal of Marketing Management, vol. 18, 341-360.

Chetverta promislova revolyuciya (2016). - Access from: http://today.mts.com.ua/posts/chetverta-promislova-revolyuciya

Col. (2013). E-commerce in International and European Union Law: The Policy of the European Union on Digital Agenda and Strategy 2020. March, 2013. University of Macedonia. - $\quad$ Access from: http://afroditi.uom.gr/jmc/wpcontent/uploads/2013/06/Research-Essay-No-11.pdf

CzechInvest (2016). Target Sector ICT. - Access from: http://www.czechinvest.org/en/ict

Dasilva, C. V., Tpkman, P., (2014). Business model: what it is and what it is not. Long Range Planning, vol. 47, 379-389.

Davies, A., Fidler, D., Gorbis, M. (2011). Future Work Skills 2020, Institute for the Future for Apollo Research Institute. - Access from: https://uqpn.uq.edu.au/files/203/LIBBY\%20MARSHALL\%20future_work_skills_2020 full_research_report_final_1.pdf

Discover ICT (2015). Europe's top locations for ICT investments. - Access from: http://itexpo.cz/2015/06/15/testovaya-novost/

Durbhakula V. V. K., Kim, D. J.,(2011). E-business for Nations: A Study of National Level E- business Adoption Factors Using Country Characteristics-Business-TechnologyGovernment Framework. Journal of Theoretical and Applied Electronic Commerce Research, vol. 6, issue 3, 1-12.

E-commerce essentials (2016). - Access from: http://www.slideshare.net/SmitSuman/ecommerce-essentials-introduction-to-ecommerce

ECOMMERCE EUROPE (2015). European B2C e-commerce Report 2015: Facts, Figures, Infographics \& Trends of 2014 and the 2015 Forecast of the European B2C e-commerce Market of Goods and Services. - Access from: https://www.ecommerceeurope.eu/facts-figures/free-light-reports

Ecommerce Europe (2016). How to ensure online merchants' right to economic and contractual freedom in the debate on geo-blocking practices. February, 2016. - Access from: http://www.ecommerce-europe.eu

ECOMMERCE GUIDES (2016). The Legal Side Ecommerce Legals and Law, E-commerce Guides, December, 2016. - 2 Access from: https://ecommerceguide.com/guides/ecommerce-legals/

ECOMMERCEWIKI (2017) Global B2C E-commerce Report 2016. Access from: https://www.ecommercewiki.org/wikis/www.ecommercewiki.org/images/5/56/Global_ B2C_Ecommerce_Report_2016.pdf

EMARKETER (2016).WWorldwide Retail Ecommerce Sales Will Reach \$1.915 Trillion This Year. August 22, 2016. - Access from: https://www.emarketer.com/Article/WorldwideRetail-Ecommerce-Sales-Will-Reach-1915-Trillion-This-

Year/1014369\#sthash.FnDaDW3s.dpuf

European Commission (2000). On certain legal aspects of information society services, in particular electronic commerce, in the Internal Market ('Directive on electronic commerce'). Directive 2000/31/EC of the European Parliament and of the Council. Access from:

http://eurlex.europa.eu/LexUriServ/LexUriServ.do?uri=CELEX:32000L0031:en:HTML

European Commission (2010). Commission Communication, Europe 2020: A strategy for smart, sustainable and inclusive growth, March, 2010. - Access from: http://eurlex.europa.eu/legal-content/EN/TXT/HTML/?uri=CELEX:52010DC2020\&from=en 
European Commission (2012). Stimulating growth and employment: an action plan for doubling the volume of e-commerce in Europe by 2015. January, 2012. - Access from: http://europa.eu/rapid/press-release_IP-12-1389_en.htm.

Gatautis, R., Vitkauskaite, E., Angulo, I., Affonso, A., (2007). SMEs in Construction Sector: Future E-business Scenarios, Ekonomika Ir Vadyba, Economics and Management, 12, 363-375.

Gonzálbez, J. M., Rodríguez, M. M., (2012). XBRL and Integrated Reporting: The Spanish Accounting Association Taxonomy approach, The International Journal of Digital Accounting Research, vol. 12, 59 - 91 .

Grande E. U., Estébanez R. P., Colomina C. M., (2011). The impact of Accounting Information Systems (AIS) on performance measures: empirical evidence in Spanish SMEs, The International Journal of Digital Accounting Research, vol. 11, 25 - 43.

Houlne, T, (2013). No Buildings. No Fear. ${ }^{\mathrm{TM}}$ The Rise of the Virtualpreneur ${ }^{\mathrm{TM}}$. - Access from: https://workingsolutions.com/no-buildings-no-fear-the-rise-of-the-virtualpreneur/

INC. (2017). Management Information Systems (MIS). - Access from: http://www.inc.com/encyclopedia/management-information-systems-mis.html

Jahankhani, H. (2002). The impact of law on e-business practices in the EU, Internet Society, INET 2002- Internet crossroads: where technology and policy intersect, 18-21 June 2002, Washington DC, USA.

Khamis, N., Sulaiman, A. and Mohezar, S. (2014). Achieving e-Business Excellence through Knowledge Management and Organizational Learning Capabilities: A Malaysian Perspective. International Journal of Economics and Management 8 (2), 343 - 364.

Khel, I. (2015). Industriya 4.0: chto takoe Chetvertaja promyshlennaya revolyuciya? - Access from: http://hi-news.ru/business-analitics/industriya-4-0-chto-takoe-chetvertayapromyshlennaya-revolyuciya.html

Kneżević, M. (2015). Specificities of Electronic Contracts. Quality - Access to Success; vol. 16 issue $147,106-112$.

Kotb, A., Roberts, C. (2011). E-business in Accounting Education: A Review of Undergraduate Accounting Degrees in the UK and Ireland. Accounting Education: an international journal, vol. 20, No. 1, 63-78.

Markides, C., Sosa, L., (2013). Pioneering and first mover advantages: the importance of business models. Long Range Planning, vol. 46, 325-334.

Molnár, T., Vancsik, J. (2016). Sustainable Competitiveness of the SME Sector Formed by Collaboration: The Prominent Role of HR. Deturope, 8, 1: 112-127

Moreira de Souza, E., César de Sousa Batista, P., (2016). Strategic Antecedents and Consequents for the Performance of E-Business Companies. Vitória-ES, 1 - 27

Nycz, M., Niedzwiedzinski, M., Polkowski, Z., (2015). Emerging Trends and Approaches in Technology and Their Impact on SMEs. Scientific Bulletin - Economic Sciences, vol. $14,10-21$.

Osterwalder, A., (2004). The business model ontology: A proposition in a design science approach. Department of Business and Economics, University of Lausanne, Masters Thesis.

Osterwalder, A., Pigneur, Y. and Tucci, C. L. (2005). Clarifying business models: origins, present, and future of the concept. Communications of the Association for Information Systems, 16, 1-25.

Pan, G., Seow, P.-S. (2016). Preparing Accounting Graduates for Digital Revolution: A Critical Review of Information Technology Competencies and Skills Development, Journal of Education for Business. 91, (3). - Access from: https://ink.library.smu.edu.sg/cgi/viewcontent.cgi?article=2473\&context=soa_research 
Poel, K., Marneffe, W., Vanlaer, W. (2016). Assessing the electronic invoicing potential for private sector firms in Belgium, The International Journal of Digital Accounting Research, vol. 16, $1-34$.

Price, D., (2013). Open: How We'll Work, Live and Learn In The Future, Crux Publishing, 190.

Ren1, Z., Hassan, T. M., Asce, M., (2007). Legal Requirements and Challenges for eBusiness within the Single Electronic European Market. Journal of Professional Issues in Engineering Education and Practice, 246-254.

Standish Group (2013): The Chaos Manifesto: Think Big, Act Small. - Access from: http://www.versionone.com/assets/img/fi les/CHAOSManifesto2013.pdf

Stanger, M., (2016). 9 ways the workplace will be different in 2050, Business Insider, January 20, 2016. - Access from: http://www.businessinsider.com/ways-the-workplace-willlook-different-in-the-future-2016-1

STATISTA (2016). Digital Market Outlook. - Access from: https://www.statista.com/outlook/243/132/e-commerce/czech-republic\#

Tanaka, S., Sithole, M. (2015). Information Technology Knowledge and Skills Accounting Graduates Need. Australia International Journal of Business and Social Science, vol. 6, No. 8, 47-52.

The Council on competitiveness ICT industry. (2016). UCC. - Access from: http://itcompete.org/

The Future of Jobs Employment, Skills and Workforce Strategy for the Fourth Industrial Revolution, January 2016. - $\quad$ Access from: http://www3.weforum.org/docs/WEF_Future_of_Jobs.pdf

UNCTAD (2015). Digital development: Report of the Secretary-General, May, 2015. Access from: http://unctad.org/meetings/en/SessionalDocuments/ecn162015d2_ru.pdf

UNCTAD (2016) UNCTAD B2C e-commerce Index 2016. UNCTAD Technical Notes on ICT for Development, No. 7. - Access from: http://unctad.org/en/PublicationsLibrary/tn_unctad_ict4d07_en.pdf

WEF (2015) World Economic Forum, Disrupting Unemployment: Business-led Solutions for Action, 2015. - Access from: http://www3.weforum.org/docs/WEF_Future_of_Jobs.pdf

WEF (2016). Future Workforce Strategy. - Access from: http://reports.weforum.org/futureof-jobs-2016/future-workforce-strategy/

WEF (2016). Global Challenge Insight Report. The Future of Jobs Employment, Skills and Workforce Strategy for the Fourth Industrial Revolution, January 2016. - Access from: http://www3.weforum.org/docs/WEF_Future_of_Jobs.pdf

WEF (2016). New Vision for Education: Fostering Social and Emotional Learning through Technology. Access from: http://www3.weforum.org/docs/WEF_New_Vision_for_Education.pdf

WEF (2016). World Economic Forum White Paper Digital Transformation of Industries: In collaboration with Accenture, Digital Enterprise, January, 2016. - Access from: http://reports.weforum.org/digital-transformation/wpcontent/blogs.dir/94/mp/files/pages/files/dti-digital-enterprise-white-paper.pdf

Yi, L., Thomas, H.R. (2009). A decision support system for the environmental impact of ICT and E-business. International Journal of Information Technology \& Decision Making, vol. 8, No. 2. 361-377. 